\title{
Pathologic Stage II Merkel Cell Carcinoma AJCC v8
}

National Cancer Institute

\section{Source}

National Cancer Institute. Pathologic Stage /l Merkel Cell Carcinoma A/CC v8. NCI

Thesaurus. Code C136883.

Stage II includes: IIA: (T2-3, N0, M0); IIB: (T4, N0, M0). T2: Maximum clinical tumor diameter more than $2 \mathrm{~cm}$ but equal to or less than $5 \mathrm{~cm}$. T3: Maximum clinical tumor diameter more than $5 \mathrm{~cm}$. T4: Primary tumor invades fascia, muscle, cartilage, or bone. NO: No regional lymph node metastasis detected on pathologic examination. M0: No distant metastasis detected on clinical and/or radiologic examination. (AJCC 8th ed.) 